\title{
Characteristic Indexes of the Household Level and Standard of Living of Agregado and Parcelero Families ${ }^{1}$
}

\author{
Reinaldo Calero, Luis Muler Manzanares, and George E. Pringle ${ }^{2}$
}

\section{INTRODUCTION}

The social relationships between land owners and agregados ${ }^{3}$ in Puerto Rico before 1941 were of a feudal pattern wherein the former exerted almost complete control over the agregado. Under this classic social system, the agregado had little recourse from demands and restrictions imposed by the land owner. This situation imposed constraints on motivations and narrowed the range of experience of this population group. As a result, their potential adjustment at the individual, family, group, and community level was seriously restricted, causing a negative effect in the social and economic development of our society.

A prime characteristic of the traditional agregado social system was that the dwelling of the agregado was located in relation to distinctive requirements of specific crops such as coffee, sugarcane, and tobacco rather than convenience of location with regard to roads, schools, running water, electric power, and other important physical resources and services. This ecological isolation adversely affected public efforts to improve the level of living of this population group. Families with 20 children or more, living in uncomfortable dwellings which lacked even the most basic elements of home conveniences and below the minimum requirements for a "decent living" were found among the agregados (6).

To deal with this and related problems in Puerto Rico, Title V of the Land Law was approved in 1941. This title of the act provided that every agregado on the Island should be entitled to hold at least 0.25 cuerda $^{4}$ of land, free of charge and on a permanent tenure basis, on which he may erect his permanent home (2). ${ }^{5}$ This provision of the Land Law has been

1 Manuscript submitted to Editorial Board May 25, 1973.

2 Associate Sociologist, Assistant Sociologist, and Economist, respectively, Agricultural Experiment Station, Mayagüez Campus, University of Puerto Rico, Río Piedras, P.R.

3 According to the Land Law of Puerto Rico an agregado is any head of a family residing in the rural zone whose home is established in a house and on land belonging to another person, or in his own house erected on land belonging to another person, and whose only means of livehood is his labor for a wage earned from agricultural tasks.

Spanish unit of land measurement equivalent to 0.9712 of an acre.

- Legislation approved by the Puerto Rican Legislature in 1969 provides title of 
considered as the starting point for the rchabilitation of this population group, since it opened an avenue for providing services and social programs for improving their living conditions. About 75,000 of these families have been resettled in rural communities, but there are still thousands of agregado families living on farms (5). ${ }^{6}$

The SPA (Social Programs Administration), a public agency entrusted with the relocation of agregados, frequently needs to evaluate the effectiveness of its programs aimed at improving the living conditions of this population group. The main purpose of this study was to measure changes in the level and standard of living, specially in housing, of the agregados and parceleros.

\section{APPROACH TO THE PROBLEM}

Level of living is defined as the position an individual or family occupies as to material cultural possessions. It may be viewed in the theory of social stratification as the material style of life, and is thus affected by the consumption and expenditure behavior of the family. Standard of living refers to those conditions sought or desired and used as a reference to assess actual conditions (1). The crux of this paper is that there are intermediate stages in level-of-living adjustments (4). When families in depressed social and economic circumstances (e.g. agregados and parceleros) are able to achieve upward level-of-living mobility through income increases or by other means, they first tend to consume items from intermediate categories of expenditures and then, as conditions continue to improve, from higher categories. Improvement of economic circumstances are thus translated in a stepwise way into higher levels of living. This process contributes to the material well-being and comfort of family life to the extent that consumption of more desirable items provide more satisfaction.

Household operations such as cooking, house cleaning, washing clothes, and recreation require physical space and material items for their performance. Although there are many ways of doing the same tasks, certain equipment or material items enable ordinary tasks to be performed more easily or efficiently than others and are therefore considered superior. For instance, other things being equal, it is less difficult to cook on an electric or gas range than on a kerosene stove, or on a kerosene stove than on a wood hearth or over a fire within three stones on the ground. These variations in the quality of material items available for a specific household purpose provide tangible information for measuring the level of living.

property of land given on a permanent tenure basis under Title V of the Land Law. These plots of land range from 0.25 to 3.0 cuerdas.

${ }^{6}$ When an agregado is resettled in a rural community, his social status of agregado changes to that of a parcelero (a parcel-holder) by virtue of the parcel or lot of land given to him on a permanent tenure basis to erect his home. 
Within this framework, data collected from a sample of 305 agregado families and 487 parcelero families were arranged into 25 groups of material and cultural items. Each group embraced those material items used to perform a given basic household function or area, such as lighting. Functionally similar items were then classified, within each area, into 5graded categories in descending order of material comfort, as judged by a panel of sociologists. Items within the 5-graded categories were initially weighted by the simple scoring method: $4,3,2,1,0$, with the highest value placed on the item providing the greatest material comfort or satisfaction and the lowest on the item contributing the least. Of the 25 initial areas,

TABLE 1.-Intercorrelations among 10 selected areas of the household level of living of the agregado and parcelero families, Puerto Rico'

\begin{tabular}{|c|c|c|c|c|c|c|c|c|c|c|}
\hline Areas & $x_{1}$ & $x_{8}$ & $x_{2}$ & $x_{4}$ & $x$ & $x_{0}$ & $x$ & $x_{0}$ & $z 8$ & $x_{10}$ \\
\hline $\begin{array}{l}X_{1} \text { Walls of the dwelling } \\
X_{2} \text { Lighting facilities } \\
X_{1} \text { Number of bedrooms } \\
X_{1} \text { Cooking facilities } \\
X_{6} \text { Bathing facilities } \\
X_{6} \text { Disposal of human } \\
\text { wastes } \\
X_{7} \text { Dishwashing facilities } \\
X_{9} \text { Facilities to preserve } \\
\text { perishable foods } \\
X_{0} \text { Washing clothes facili- } \\
\text { ties } \\
X_{10} \text { Recreation facilities in } \\
\text { the dwelling }\end{array}$ & 1.000 & $\left|\begin{array}{l}0.394 \\
1.000\end{array}\right|$ & $\begin{array}{r}0.361 \\
.340 \\
1.000\end{array}$ & $\mid \begin{array}{r}0.440 \\
.426 \\
.510 \\
1.000\end{array}$ & $\begin{array}{r}0.369 \\
.313 \\
.333 \\
.441 \\
1.000\end{array}$ & $\begin{array}{r}0.358 \\
.356 \\
.266 \\
.470 \\
.430 \\
1.000\end{array}$ & $\mid \begin{array}{r}0.351 \\
.339 \\
.291 \\
.429 \\
.373 \\
.434 \\
1.000\end{array}$ & $\begin{array}{r}0.385 \\
.297 \\
.253 \\
.402 \\
.343 \\
.317 \\
\\
.259 \\
1.000\end{array}$ & \begin{tabular}{|}
0.314 \\
.283 \\
.304 \\
.360 \\
.378 \\
.370 \\
\\
.382 \\
.257 \\
1.000
\end{tabular} & $\begin{array}{r}0.244 \\
.274 \\
.433 \\
.500 \\
.282 \\
.381 \\
\\
.313 \\
.297 \\
.321 \\
1.000\end{array}$ \\
\hline
\end{tabular}

1 Correlations between all possible pairs of areas are significant at the 1-percent level of probability.

10 were retained for analysis. Each of them was correlated to every other in the sample (table 1).

The discriminate function technique was used to compute characteristic indexes that position agregado or parcelero families on the level and standard-of-living scale.

\section{THE DATA}

Rural people are increasingly influenced in their goals and aspirations by cosmopolitan forces, particularly in a socio-cultural setting such as Puerto Rico, where most rural localities lie at close distances from some major urban areas. Table 2 shows some of the more pervasive changes in level of living that have occurred among the agregado and parcelero families, and 


\begin{tabular}{|c|c|c|c|c|c|c|c|c|c|c|}
\hline \multirow{4}{*}{ Areas and categories } & \multicolumn{10}{|c|}{ Multivariate distribution of the responses } \\
\hline & \multicolumn{6}{|c|}{ Parceleros } & \multicolumn{4}{|c|}{ Agregados } \\
\hline & \multicolumn{2}{|c|}{$\begin{array}{l}\text { Inmediately before } \\
\text { they were. resettled }\end{array}$} & \multicolumn{2}{|c|}{$\begin{array}{l}\text { At the time of the } \\
\text { interview }\end{array}$} & \multicolumn{2}{|c|}{ Aspirations } & \multicolumn{2}{|c|}{$\begin{array}{l}\text { At the time of } \\
\text { the interview }\end{array}$} & \multicolumn{2}{|c|}{ Aspirations } \\
\hline & Number & Percent & Number & Percent & Number & Percent & Number & Percent & Number & Percent \\
\hline \multicolumn{11}{|l|}{ A. Walls of dwelling } \\
\hline a. Concrete or blocks & 6 & 1.2 & 382 & 78.4 & 480 & 98.6 & 18 & 5.9 & 248 & 81.3 \\
\hline b. Painted wood & 54 & 11.1 & 62 & 12.8 & 5 & 1.0 & 86 & 28.2 & 48 & 15.7 \\
\hline c. Unpainted wood & 330 & 67.8 & 41 & 8.4 & 2 & 0.4 & 179 & 58.7 & 9 & 3.0 \\
\hline d. Zinc & 21 & 4.3 & 2 & 0.4 & 0 & 0.0 & 19 & 6.2 & 0 & 0.0 \\
\hline e. Tarpaper, straw or palm leaves & 76 & 15.6 & $\mathbf{0}$ & 0.0 & $\mathbf{0}$ & 0.0 & 3 & 1.0 & $\mathbf{0}$ & 0.0 \\
\hline Total & 487 & 100.0 & 487 & 100.0 & 487 & 100.0 & 305 & 100.0 & 305 & 100.0 \\
\hline \multicolumn{11}{|l|}{ B. Lighting facilities in living room } \\
\hline ฉ. Wall or ceiling electric lamps & 2 & 0.4 & 232 & 47.6 & 415 & 85.2 & 45 & 14.8 & 211 & 69.2 \\
\hline b. Electric bulb & 150 & 30.8 & 247 & 50.7 & 72 & 14.8 & 229 & 75.1 & 93 & 30.5 \\
\hline c. Kerosene burner lamps and lanterns & 8 & 1.6 & $\mathbf{0}$ & 0.0 & $\mathbf{0}$ & 0.0 & $\mathbf{0}$ & 0.0 & $\mathbf{0}$ & 0.0 \\
\hline d. Lanterns & 278 & 57.1 & 7 & 1.5 & 0 & 0.0 & 21 & 6.8 & 1 & 0.3 \\
\hline e. Kerosene lamp or candles & 49 & 10.1 & 1 & 0.2 & 0 & 0.0 & 10 & 3.3 & 0 & 0.0 \\
\hline Total & 487 & 100.0 & 487 & 100.0 & 487 & 100.0 & 305 & 100.0 & 305 & 100.0 \\
\hline \multicolumn{11}{|l|}{ C. Number of bedrooms } \\
\hline a. Four or more & 1 & 0.2 & 70 & 14.4 & 294 & 60.4 & 16 & 5.3 & 120 & 39.3 \\
\hline b. Three & 37 & 7.6 & 202 & 41.5 & 149 & 30.6 & 61 & 20.0 & 125 & 40.9 \\
\hline c. Two & 213 & 43.7 & 197 & 40.4 & 43 & 8.8 & 141 & 46.2 & 55 & 18.3 \\
\hline d. One & 227 & 46.6 & 17 & 3.5 & 1 & 0.2 & 82 & 26.9 & $\mathbf{5}$ & 1.5 \\
\hline e. None & 9 & 1.9 & 1 & 0.2 & 0 & 0.0 & $\mathbf{5}$ & 1.6 & 0 & 0.0 \\
\hline Total & 487 & 100.0 & 487 & 100.0 & 487 & 100.0 & 305 & 100.0 & 305 & 100.0 \\
\hline \multicolumn{11}{|l|}{ D. Cooking facilities } \\
\hline a. Electric or gas range stove & 9 & 1.9 & 326 & 66.9 & 441 & 90.6 & 136 & 44.6 & 257 & 84.2 \\
\hline b. Kerosene stove & 164 & 33.7 & 149 & 30.6 & 45 & 9.2 & 110 & 36.1 & 44 & 14.4 \\
\hline c. Charcoal bearth & 61 & 12.5 & 1 & 0.2 & 1 & 0.2 & 4 & 1.3 & 2 & 0.7 \\
\hline d. Wood hearth & 248 & 50.9 & 11 & 2.3 & $\mathbf{0}$ & 0.0 & 53 & 17.4 & 2 & 0.7 \\
\hline e. Three stones on floor & 5 & 1.0 & 0 & 0.0 & $\mathbf{0}$ & 0.0 & 2 & 0.6 & $\mathbf{0}$ & 0.0 \\
\hline Total & 487 & 100.0 & 487 & 100.0 & 487 & 100.0 & 305 & 100.0 & 305 & 100.0 \\
\hline
\end{tabular}


TABLE 2.-Continued

\begin{tabular}{|c|c|c|c|c|c|c|c|c|c|c|}
\hline \multirow{5}{*}{ Areas and categories } & \multicolumn{10}{|c|}{ Multivariate distribution of the responses } \\
\hline & \multicolumn{6}{|c|}{ Parceleros } & \multicolumn{4}{|c|}{ Agregados } \\
\hline & \multicolumn{2}{|c|}{$\begin{array}{l}\text { Inmediately before } \\
\text { they were resettled }\end{array}$} & \multicolumn{2}{|c|}{$\begin{array}{l}\text { At the time of the } \\
\text { intervien }\end{array}$} & \multicolumn{2}{|c|}{ Aspirations } & \multicolumn{2}{|c|}{$\begin{array}{l}\text { At the time of } \\
\text { the interview }\end{array}$} & \multicolumn{2}{|c|}{ Aspirations } \\
\hline & Number & Percent & Number & Percent & Number & Percent & Number & Percent & Number & Percent \\
\hline & & & & & & & & & & \\
\hline $\begin{array}{l}\text { a. Bathroom with washstand, bathlub } \\
\text { and shower }\end{array}$ & 0 & $\mathbf{0}$ & 25 & 5.1 & 328 & 67.4 & 2 & 0.7 & 138 & 45.3 \\
\hline $\begin{array}{l}\text { b. Bathroom with washstand and } \\
\text { shower only }\end{array}$ & 1 & 0.2 & 48 & 9.9 & 109 & 22.4 & 9 & 3.0 & 74 & 24.3 \\
\hline c. Bathroom with shower only & 41 & 8.4 & 291 & 59.8 & 45 & 9.2 & 79 & 25.0 & 90 & 29.5 \\
\hline $\begin{array}{l}\text { d. Punch bowls, washbowls or bombs } \\
\text { of zinc }\end{array}$ & 334 & 68.6 & 116 & 23.8 & 4 & 0.8 & 177 & 58.0 & 2 & 0.6 \\
\hline e. Tin vessels, "higüeras,"' etc. & 111 & 22.8 & 7 & 1.4 & 1 & 0.2 & 38 & 12.4 & 1 & 0.3 \\
\hline Total & 487 & 100.0 & 487 & 100.0 & 487 & 100.0 & 305 & 100.0 & 305 & 100.0 \\
\hline \multicolumn{11}{|l|}{ F. Disposal of human wastes } \\
\hline a. Toilet inside house & $\mathbf{0}$ & 0.0 & 63 & 12.9 & 431 & 88.6 & 17 & 5.6 & 237 & 77.8 \\
\hline b. Toilet outside house & $\mathbf{3}$ & 0.6 & 23 & 4.7 & 24 & 4.9 & 1 & 0.3 & 20 & 6.5 \\
\hline $\begin{array}{l}\text { c. Concrete or block latrine or com- } \\
\text { mercial wood and zinc latrine }\end{array}$ & 181 & 37.2 & 390 & 80.1 & 32 & 6.6 & 202 & 66.2 & 48 & 15.7 \\
\hline $\begin{array}{l}\text { d. Latrine made with pieces of card } \\
\text { board or pieces of zinc, etc. }\end{array}$ & 284 & 58.3 & 10 & 2.1 & 0 & 0.0 & 64 & 21.0 & 0 & 0.0 \\
\hline e. None & 19 & 3.9 & 1 & 0.2 & 0 & 0.0 & 21 & 6.9 & 0 & 0.0 \\
\hline Total & 487 & 100.0 & 487 & 100.0 & 487 & 100.0 & 305 & 100.0 & 305 & 100.0 \\
\hline \multicolumn{11}{|l|}{ G. Dish-washing facilities } \\
\hline a. Electrical dishwasher & 0 & 0.0 & 4 & 0.8 & 36 & 7.4 & $\mathbf{0}$ & 0.0 & $\mathbf{5}$ & 1.7 \\
\hline $\begin{array}{l}\text { b. Sink with hot and cold running } \\
\text { water }\end{array}$ & 0 & 0.0 & 17 & 3.5 & 249 & 51.1 & 3 & 1.0 & 69 & 22.6 \\
\hline c. Sink with cold running water only & 45 & 9.2 & 330 & 67.8 & 200 & 41.1 & 109 & 35.7 & 219 & 71.8 \\
\hline d. Sink without running water & 107 & 22.0 & 98 & 20.1 & 2 & 0.4 & 113 & 37.1 & 11 & 3.6 \\
\hline e. Washes in vessels, pails, cans, etc. & 335 & 68.8 & 38 & 7.8 & 0 & 0.0 & 80 & 26.2 & 1 & 0.3 \\
\hline
\end{tabular}


H. Facilities to preserve perishable foods
a. Freezer
b. Electric or gas refrigerator
c. Ice box
d. Shelves to keep them fresh
e. Tin, cans, sacks, etc.
Total

I. Washing clothes, facilities
a. Automatic washing machine
b. Semi-automatic washing machine
c. Basin with running water faucets
d. Trough or zinc bowl
e. Trough made of petiole of the palm tree$$
\text { Total }
$$

J. Recreation facilities in house
a. Television, radio and phonograph
b. Television and radio or television and phonograph
c. Television only
d. Radio or phonograph
e. None Total

$\begin{array}{rrr}0 & 0.0 & 4 \\ 58 & 11.9 & 445 \\ 4 & 0.8 & 0 \\ 169 & 34.7 & 25 \\ 256 & 52.6 & 13 \\ 487 & 100.0 & 487\end{array}$

$\begin{array}{rrr}0.8 & 40 & 8.2 \\ 91.4 & 446 & 91.6 \\ 0.0 & 1 & 0.0 \\ 5.1 & 0 & 0.0 \\ 2.7 & 0 & 0.0 \\ 100.0 & 487 & 100.0\end{array}$

9

205

2.9
67.2

67.2
0.0

0.0
10.2

19.7

100.0

$\begin{array}{rrr}0 & 0.0 & 42 \\ 6 & 1.2 & 86 \\ 4 & 0.8 & 70 \\ 334 & 68.6 & 279 \\ 143 & 29.4 & 10\end{array}$

$8.6 \quad 213$

$17.7 \quad 191$

100.0

305

43.7

39.2

$\begin{array}{rrr}14.4 & 57 & 11.8 \\ 57.3 & 26 & 5.3\end{array}$

$\begin{array}{lll}2.0 & 0 & 0.0\end{array}$

$\begin{array}{rrrr}10 & 3.3 & 92 & 30.2 \\ 16 & 5.3 & 100 & 32.8 \\ 11 & 3.6 & 65 & 21.3 \\ 202 & 66.2 & 44 & 14.4 \\ 66 & 21.6 & 4 & 1.3\end{array}$

$\begin{array}{lll}487 & 100.0 & 487\end{array}$

$100.0 \quad 487$

100.0

.305

100.0

305

100.0

$13.3 \quad 233$

47.8

48.5

29

9.5

173

56.7

$\begin{array}{rrr}2 & 0.4 & 65 \\ 16 & 3.3 & 265\end{array}$

$54.5 \quad 236$

121

36.1

\begin{tabular}{rrrrrrrrrr}
1 & 0.2 & 12 & 2.5 & 10 & 2.0 & 12 & 3.9 & 6 & 1.9 \\
114 & 23.4 & 131 & 26.9 & 7 & 1.4 & 118 & 38.7 & 16 & 5.3 \\
354 & 72.7 & 14 & 2.9 & 1 & 0.3 & 25 & 8.2 & 0 & 0.0 \\
487 & 100.0 & 487 & 100.0 & 487 & 100.0 & 305 & 100.0 & 305 & 100.0 \\
\hline
\end{tabular}

${ }^{1}$ Bailer or drinking utensil made from the hard-shell fruit of the calabash tree. 
focuses attention to the norms or standards of living sought after by these rural residents. Items in the table are classified within 5-graded categories in 10 functional areas of household material and cultural possessions. An examination of the frequency distributions within each category indicates, as one moves from previous to present to aspired conditions, that the values are increasingly oriented toward those items judged superior in convenience or satisfaction. These trends are evident for both agregados and parceleros, but changes taking place are more pronounced among the latter.

Housing is one of the more visible factors contributing to level of living. It is noteworthy that as the agregados move from farms to SPA communities, unpainted wood units are left behind for concrete or block housing newly constructed with the help of neighbors. ${ }^{7}$ For instance, of the 487 parceleros interviewed, 67.8 percent reported living in houses with unpainted walls prior to resettlement. During the analysis year, 78.4 percent of the parceleros were living in concrete or block wall units. By way of contrast, only 5.9 percent of the agregado families reported living in housing with concrete or wood walls, 58.7 percent were living in homes with unpainted wood walls, 28.2 percent in painted rood dwellings, and 7.2 percent in housing with wall construction of zinc, tarpaper, or other materials.

The homes of the parceleros are now larger than before resettlement, as are those now occupied by agregados. Over 90 percent of the parceleros lived in homes of only one or two bedrooms before resettlement; 55.9 percent now have homes with either 3 or 4 bedrooms. Among the agregados, 73.1 percent were living in 1- or 2-bedroom homes and 20.0 percent in 3bedroom homes, during the study year. Over 90 percent of the parceleros and 80 percent of the agregados aspired to live in 3- or 4-bedroom homes.

Availability of electric power in rural areas is of major importance to quality of life, for its access makes possible a large number of services and material items that provide convenience and comfort. For instance, 57.1 percent of the parceleros reported the use of kerosene lamps and 97.1 percent the use of kerosene, charcoal, or wood stoves prior to moving to SPA communities. With increased availability of electricity following resettlement, nearly all the parceleros had some form of electric lighting, and about two-thirds had electric refrigerators during the analysis year.

Improvements in facilities for bathing, washing dishes and clothes, recreation and the like are also closely associated with life in parcelero communities.

${ }^{7}$ An interesting dimension of the program was the construction of low-cost housing in these rural communities on a mutual-help basis. This program, known as the "Low-Cost Housing Through Own Efforts and Mutual Help," provided a mechanism for solving housing needs of relocated agregados. 


\section{THE MODEL}

For a quantitative interpretation of the stages by which families move toward a definite standard of living, it was considered that the process might be expressed by a linear rather than a non-linear model. The different stages could then be characterized by the set of linear functions that might successfully distinguish among these stages on the basis of the graded-item categories of the different areas of the household consumption pattern, as shown in table 2.

These considerations suggested that a linear discriminant function might be used to provide an index useful for the classification of individuals on the basis of their relative position within the area, as determined by the weights assigned to the material or culture items they possessed or aspire to. The characteristic indexes provided by the function might be used for a direct statistical comparison of the groups at the same or different time periods. Should the discriminant function technique be useful in this connection, a model then might be available to study the level of living as a process in both social settings. Visualize the model on the temporal-spacial scheme below:

$Y_{10}=$ previous household level of living of the parceleros immediately before they were resettled in rural communities by the SPA

$Y_{11}=$ household level of living of the parceleros at time of interview

$Y_{12}=$ household standard of living of the parceleros

$Y_{21}=$ household level of living of the agregados at time of interview

$Y_{22}=$ household standard of living of the agregados

Hence, the basic linear discriminant function used to estimate the characteristic index corresponding to each point of time and location would be:

$$
Y_{\mathrm{ij}}=M+A X_{\mathrm{a}}+B X_{\mathrm{b}}+C X_{\mathrm{o}}+D X_{\mathrm{d}}+E X_{\mathrm{o}} \cdots \text {, }
$$

where $M$ is the regression constant and $A, B, C, D$, and $E$ denote the weights (regression coefficients) estimated for each of the areas on which the household level of living depends: walls of the dwellings, lighting facilities, number of bedrooms, etc. The $X$ 's refer to the scores corresponding to the various areas. The procedure for estimating the regression constant and the weights given to the levels in estimating the indexes was developed by Capó and used by Moscoso and Capó (3) in objectively discriminating among orange, grapefruit, and chironja on the basis of certain measured characters.

The first step in this fitting is to bring to a similar scale the 5-graded item category scores of the household consumption pattern. To do this, the area score of each individual was divided by the general mean area score for all individuals. In the method developed by Capo, the mean of these ratios for an individual is regarded as a tentative characteristic index of 
the individual. The mean of these tentative characteristic indexes for all the individuals of a group is then assumed to be the characteristic index of the group and is used to represent the initial level-of-living value of each and every individual of the group in the first fitting of the regression or discriminant function.

After estimating the values of the constants of the equation by the method of least squares, the fitted equation is used to calculate a corrected characteristic index for each group by substituting in the equation the mean area level of the group. The equation is then fitted again to the data using these corrected indexes as values of the dependent factor, and the process is repeated until the values of the constants become stable. Thus, the best fit is reached by iteration, that is, a series of successive approximations. The resulting weighted coefficients are shown in table 3.

Walls of the dwelling (A) obtained the highest coefficient, 0.20336 , showing that quality of housing is of major significance as an indicator of level of living.

The mean scores for specified categories of material and cultural possessions at a given time, or desired by the agregados and parceleros, are shown in table 4. These computations provide a measure of changes in quality of possessions for each subarea, and provide the basis for calculating the value of the discriminant functions corresponding to agregados and parceleros in different spacial and temporal settings. ${ }^{8}$

\section{RESULTS}

The fitted discriminant function explained 97 percent of the variation among the individual estimated levels of living. The hypothesis that there are no differences in level of living among the parcelero and agregado groups in time and space is therefore rejected at the 1-percent level of probability.

The following tabulation shows the value of the discriminat functions corresponding to agregados and parceleros in different spatial and temporal settings:

\section{Factor}

Level of living, agregados Level of living, parceleros
Value of discriminant function

0.142266 .193180

${ }^{8}$ Computation of the value for living conditions of the parceleros prior to resettlement provides an example of the calculation. Substituting the corresponding coefficient from table 3 and the mean scores from table 4 in the formula:

$$
X_{10}=M+A X_{1}+B X_{2} \cdots J X_{10} \text { we have }
$$

$Y_{10}=0.001566+0.020336(1.7793)+0.008629(1.5463)+0.006192(1.5773)+0.008261(1.8474)$

$+0.004219(0.8577)+0.012843(1.3483)-0.001401(0.4061)+0.001598(0.7195)-0.00339$

$(0.7381)+0.000520(0.3546)=0.097582$ 
TABLE 3.-A metric of the household level and slandard of living of the agregado and parcelero families, Puerto Rico

\begin{tabular}{lr}
\hline \multicolumn{1}{c}{ Variables } & $\begin{array}{c}\text { Mea } \\
\text { sure } \\
\text { ment }\end{array}$ \\
\hline A. Walls of dwelling & $\left(W_{1}\right)$ \\
a. Concrete or blocks & 4 \\
b. Painted wood & 3 \\
c. Unpainted wood & 2 \\
d. Zinc & 1 \\
e. Tarpaper, straw or palm & 0
\end{tabular}

B. Lighting facilities in living room
a. Wall or ceiling electric lamps
b. Electric bulb
c. Kerosene burner lamps and lanterns
d. Lanterns
e. Kerosene lamp or candles
4
3
2

0

0.008629

\begin{tabular}{cc}
$\begin{array}{c}\text { Weights for the } \\
\text { ittem cantegories } \\
\text { within each } \\
\text { subarea }\end{array}$ & $\begin{array}{c}\text { System of } \\
\text { weights } \\
\text { adopted }\end{array}$ \\
\hline$\left(W_{3}\right)\left(W_{2}\right)$ & $\left(W_{1}\right)\left(W_{2}\right) 100$
\end{tabular}

0.020336

C. Number of bedrooms:
a. Four or more
b. Three
c. Two
d. One
e. None

4

(3)

0.081344

8.1

0.061008

0.040672

0.020336

0.000000

6.1

4.1

2.0

0.0

$\begin{array}{ll}0.034516 & 3.5 \\ 0.025887 & 2.6 \\ 0.017258 & 1.7 \\ & \\ 0.008629 & 0.9 \\ 0.000000 & 0.0\end{array}$

0.006192

$\begin{array}{ll}0.024768 & 2.5 \\ 0.018576 & 1.9 \\ 0.012384 & 1.2 \\ 0.006192 & 0.6 \\ 0.000000 & 0.0\end{array}$

0.008261
a. Electric or gas range stove
b. Kerosene stove
c. Charcoal hearth stove
d. Wood bearth stove
e. Three stones on ground

0.004219

$\begin{array}{ll}0.033044 & 3.3 \\ 0.024783 & 2.5 \\ 0.016522 & 1.7 \\ 0.008261 & 0.8 \\ 0.000000 & 0.0\end{array}$

E. Batbing facilities

a. Bathroom with washstand, bathtub and shower

b. Bathroom with washstand and 3 shower only

c. Bathroom with shower only 2

d. Punch bowls, wash bowls, or 1 bombs of zinc

e. Tin vessels, "higüeras",'1 etc. 0

F. Disposal of buman wastes
a. Toilet inside house
b. Toilet outside house
c. Concrete or block latrine, or commercial wood and zinc latrine
d. Latrine made with pieces of 1 cardboard, zinc, etc.

e. None

0.016876

0.012657

0.008438

0.004219

0.8

0.4

$0.000000 \quad 0.0$

0.012843

b

$0.051372 \quad 5.1$

0.038529

3.9

0.025686

2.6

$0.012843 \quad 1.3$

$\begin{array}{ll}0.000000 & 0.0\end{array}$ 
TABLE 3-Continued

\begin{tabular}{lr}
\hline \multicolumn{1}{c}{ Variables } & $\begin{array}{c}\text { Mea } \\
\text { sure } \\
\text { men }\end{array}$ \\
\hline & $\left(W_{1}\right)$ \\
G. Dishwashing facilities \\
a. Electric dishwasher \\
b. Sink with hot and cold run- \\
$\quad \begin{array}{l}\text { ning water } \\
\text { c. Sink with cold running water }\end{array}$ & 2 \\
$\quad \begin{array}{l}\text { only } \\
\text { d. Sink without running water } \\
\text { e. Washes in vessels, pails, cans, }\end{array}$ & 1 \\
$\quad$ etc. & 0
\end{tabular}

H. Facilities to preserve perishable foods
a. Freezer
b. Electric or gas refrigerator
c. Ice box
d. Shelves to keep them fresh
c. Tins, cans, sacks, etc.

\begin{tabular}{cc} 
Mea- & $\begin{array}{c}\text { Discriminan } \\
\text { function } \\
\text { coefficients } \\
\text { ment } \\
\text { meights }\end{array}$ \\
\hline
\end{tabular}

Weights for the

item categories

vithin each weights subarea

accepted

$\left(V_{1}\right)$

$\left(\mathrm{W}_{2}\right)$

$\left(W_{1}\right)\left(W_{2}\right)$

$\left(W_{1}\right)\left(W_{2}\right) 100$

$-0.001401$

Washing clothes facilities

a. Automatic washing machine 4

b. Semi-automatic washing ma- 3 chine

c. Basin with running water 2 faucets

d. Trough or zinc bowl 1

e. Trough made of petiole of 0 palm tree

J. Recreation facilities in house

a. Television, radio and phono- 4 graph

b. Television and radio or televi- 3 sion and phonograph

c. Television

d. Radio or phonograph

e. None

$\mathbf{4}$
$\mathbf{3}$
$\mathbf{2}$
$\mathbf{1}$
$\mathbf{0}$

0.001598

$\begin{array}{rr}-0.005604 & -0.6 \\ -0.004203 & -0.4 \\ & \\ -0.002802 & -0.3 \\ & \\ -0.001401 & -0.1 \\ 0.000000 & 0.0\end{array}$

0.001598

1 See footnote 1 , table 2.

$\begin{array}{lc}\text { Factor } & \text { Value of discriminant } \\ & \text { function } \\ \text { Previous level of living, parceleros } & .097582 \\ \text { Standard of living, agregados } & .223391 \\ \text { Standard of living, parceleros } & .235747\end{array}$

The implications of these discriminant function applications may in general be stated as follows: The highest computed value 0.235747 cor- 
responds to the standard of living of the parcelero families and the lowest value, 0.097582 , to their living conditions prior to resettlement. The vlaue 0.193180 , for the linear combination that characterizes their existing level of living is in between, indicating an intermediate stage in this process. The differences between previous living conditions on farms and existing conditions in rural communities are highly significant. The same conclusion holds with respect to the difference between the standard of living or conditions of life to which parceleros aspire and the level of living already attained in rural communities.

Parallel but less marked changes are observed among the agregado

TABLE 4.-Mean household area levels of living of the parcelero and agregado families, Puerto Rico, 1970

\begin{tabular}{|c|c|c|c|c|c|c|}
\hline \multirow{3}{*}{\multicolumn{2}{|c|}{ Selected areas (variables) }} & \multicolumn{5}{|c|}{ Group means } \\
\hline & & \multicolumn{3}{|c|}{ Parceleros } & \multicolumn{2}{|c|}{ Agregados } \\
\hline & & $\begin{array}{l}\text { Immedi- } \\
\text { atelyy } \\
\text { beforc } \\
\text { resettle- } \\
\text { ment }\end{array}$ & $\begin{array}{l}\text { At time of } \\
\text { interview }\end{array}$ & $\begin{array}{l}\text { Aspira- } \\
\text { tions }\end{array}$ & $\begin{array}{l}\text { At time of } \\
\text { interview }\end{array}$ & Aspirations \\
\hline$X_{1}$ & Walls of the dwelling & 1.7793 & 3.6907 & 3.9814 & 2.3245 & 3.7704 \\
\hline$X_{2}$ & Lighting facilities & 1.5463 & 3.4412 & 3.8515 & 2.9147 & 3.6721 \\
\hline$X_{8}$ & Number of bedrooms & 1.5773 & 2.6618 & 3.5113 & 2.0032 & 3.1704 \\
\hline$X_{4}$ & Cooking facilities & 1.8474 & 3.6226 & 3.9030 & 3.0655 & 3.8098 \\
\hline$X_{5}$ & Bathing facilities & .8577 & 1.9340 & 3.5525 & 1.2131 & 3.1344 \\
\hline$X_{0}$ & Disposal of human wastes & 1.3483 & 2.2927 & 3.8226 & 1.7672 & 3.6196 \\
\hline$X_{7}$ & Dishwashing facilities & .4061 & 1.6927 & 2.6536 & 1.1147 & 2.2163 \\
\hline$X_{8}$ & $\begin{array}{l}\text { Facilities to preserve per- } \\
\text { ishable foods }\end{array}$ & .7195 & 2.8206 & 3.0804 & 2.2360 & 3.0557 \\
\hline$X_{\theta}$ & Washing clothes facilities & .7381 & 1.7340 & 3.2103 & 1.0229 & 2.7606 \\
\hline$X_{10}$ & Recreation facilities & .3546 & 2.4824 & 3.4247 & 2.0360 & 3.4426 \\
\hline
\end{tabular}

families. For instance, the value in the discriminant function for their standard of living is 0.223391 and the value for their level of living is 0.142266 . Thus, if the value 0.097582 corresponding to previous living conditions on the farms is also taken as a starting point for level-of-living changes among this group, the agregados clearly appear to be progressing through a less advanced phase in the process than parceleros. The differences between previous and existing levels of living of the agregados, as well as the discrepancies between their standard and level of living, are also significant at the 1-percent level of probability.

An important conclusion from this analysis is that the SPA can point to some success in raising levels of living among parceleros. Although the current level of living of the agregados, as well as that of the parceleros, differ 
significantly from their previous living conditions, changes taking place in both social settings are more favorable among the parceleros. The differences between them with respect to the level of living achieved are highly significant.

The ratio of deprivation (discrepancies between the standard and level of living as a ratio of the standard of living of each group) is also more pronounced among agregados than parceleros, particularly as they do not differ significantly with respect to aspirations to improve the level of living. In contrast to their existing level of living, the null hypothesis could not be rejected when both groups were compared with respect to their standard of living.

\section{SUMMARY}

This paper presents changes in the level and standards of living of agregado and parcelero families in Puerto Rico. The discriminant function technique was used to compute characteristic indexes of the material style of life attained at a given time or desired by both groups under study. The analyses showed that important changes have occurred in the levels of living of the agregado and the parcelero families, but the changes are more marked among the parcelero families.

The analyses also identified intermediate stages in the level-of-living process. The agregados also appeared to be progressing through a lessadvanced phase in this process than the parceleros.

An important conclusion from the study is that the SPA can point to some success in establishing conditions wherein levels of living have been raised among the parceleros.

\section{RESUMEN}

En este estudio se presentan los cambios que han ocurrido en el nivel y estándar de vida de las familias de agregados y parceleros. Para computar los índices característicos del estilo material de vida deseado o logrado por ambos grupos en un perfodo determinado, se utilizaron técnicas de la función discriminatoria. Los análisis demostraron que se han registrado cambios importantes en sus niveles de vida, pero las mejoras que se evidencian son más pronunciadas en las familias de parceleros que en las de agregados.

Los análisis también identificaron etapas intermedias en el proceso del nivel de vida y demostraron que la etapa en que se encuentran los agregados está en una fase más atrasada que la de los parceleros.

Una conclusión importante que se desprende de este estudio es que la Administración de Programas Sociales ha tenido éxito en establecer condiciones propicias al mejoramiento de los niveles de vida de los parceleros.

\section{LITERATURE CITED}

1. Collazo, J., Ríos Mariano, J., and Ramsey, E. C., Development of a Level-ofLiving Scale for Puerto Rican Rural Families, Agr. Exp. Sta. Univ. P.R. Bull. 156, pp. 8-9, Oct. 1960. 
2. Legislación Agrícola Vigente en Puerto Rico, Suplemento de 1941, Dep. Agr. and Com., San Juan, P.R.

3. Moscoso, C. G., and Capó, B. G., Characteristic Discriminant Function Indexes of Chironja, Orange and Grapefruit, J. Agr. Univ. P.R. 57(1):65-7, 1973.

4. Ramsey, E. C., and Collazo, J., Some Problems of Cross-Cultural Measurement, reprinted from Rural Sociol. 25(1): 104-5, March 1960.

5. United States Census of Agriculture, 1964, Vol. 1, Part 52, Puerto Rico, Bur. of the Census, U.S. Dep. of Com.

6. Váqquez Calcerrada, P. B., The Study of a Planned Rural Community in Puerto Rico, Agr. Exp. Sta. Univ. P.R. Bull. 109, pp. 11-15, April 1953. 